Jonas C. Rybarz

\title{
Billigkeitserwägungen im Kontext des Europäischen Privatrechts
}

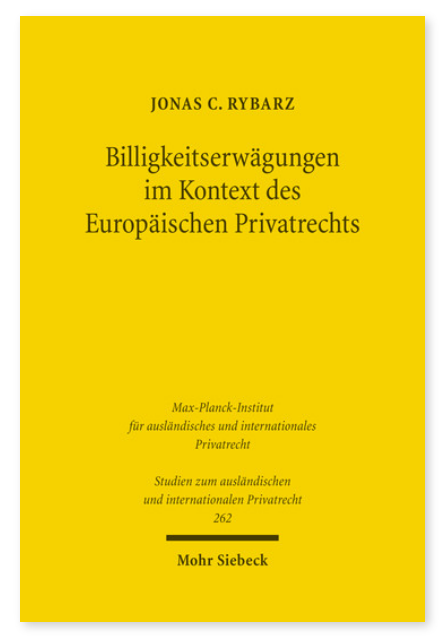

2011. XXI, 210 Seiten. StudIPR 262

ISBN 978-3-16-151447-0

eBook PDF 64,00€

ISBN 978-3-16-150818-9

fadengeheftete Broschur $64,00 €$
Das europäische Privatrecht wirkt zunehmend auf die nationalen Zivilrechtssysteme ein. Infolge des eindimensionalen Regelungsansatzes führt die Anwendung des europäischen Privatrechts im Einzelfall jedoch immer wieder zu ungerechten Ergebnissen. Aufgrund des unionsrechtlichen Anwendungsvorranges können Billigkeitsdefizite des europäischen Privatrechts dabei allein auf Unionsebene ausgeglichen werden.

Jonas C. Rybarz versucht daher durch die Analyse einzelner EuGH-Entscheidungen und durch den Vergleich mitgliedstaatlicher Privatrechtsordnungen allgemeine Zivilrechtsprinzipien auf Unionsebene aufzudecken. Mit Hilfe der gefundenen Ergebnisse sollen in Zukunft auch im Kontext des europäischen Privatrechts bei der Rechtsanwendung im Einzelfall Ergebnisse erzielt werden können, die mit den nationalen Gerechtigkeitsvorstellungen vereinbar sind.

Jonas C. Rybarz Geboren 1983; Studium der Rechtswissenschaften an der Freien Universität Berlin; 2010 Promotion; seit 2010 Referendar am Kammergericht in Berlin.
Jetzt bestellen:

https://mohrsiebeck.com/buch/billigkeitserwaegungen-im-kontext-des-europaeischen-privatrechts-9783161514470? no_cache=1

order@mohrsiebeck.com

Telefon: +49 (0)7071-923-17

Telefax: +49 (0)7071-51104 